\title{
Nondestructive Estimation of Shortgrass Aerial Biomass
}

\author{
SAMUEL C. WILLIAMSON, JAMES K. DETLING, JERROLD L. DODD, AND MELVIN I DYER
}

\begin{abstract}
A nondestructive technique for estimation of aboveground biomass of blue grama [Bouteloua gracilis (H.B.K) Griffiths] was designed for use on small sampling units $\left(<1 \mathrm{~m}^{2}\right)$. The technique combines measures of percent basal cover and mean total blade length per tiller and is recommended for experiments, such as small plot manipulations, that require an accurate and precise sampling method.
\end{abstract}

\section{Key Words: Bouteloua gracilis, shortgrass steppe, sampling methods}

In recent studies involving repeated measures of blue grama (Bouteloua gracilis) biomass on small $\left(l<\mathrm{m}^{2}\right)$ plots in the shortgrass steppe (Williamson 1983), several nondestructive herbaceous sampling methods were tried, including visual estimation and height and density measurements (Reppert et al. 1962, 't Mannetje 1976, Tothill 1976). None of these methods possessed the degree of accuracy and precision under a variety of phenological stages and meteorological conditions required for our investigations. Others have used the product of ground cover and sward height to estimate graminoid biomass (Pasto et al. 1957, Evans and Jones 1958); however, methods based on maximum plant height do not provide reliable estimates of blue grama standing crop (Crafts 1938). Pasto et al. (1957) concluded that such methods have limited practicality until some alternative to use of maximum plant height as an indicator of plant standing crop is developed. We therefore developed an alternative, nondestructive method for estimating aboveground standing crop. Based on ground cover and total blade length per tiller, this new method has a high predictive capacity for estimating aerial biomass of blue grama.

\section{Materials and Methods}

The study site was located $35 \mathrm{~km}$ northeast of Fort Collins, Colo., on the southwestern edge of the USDA Agricultural Research Service's Central Plains Experimental Range. Climate and vegetation of the study area have been described by Lauenroth et al. (1978). All studies were conducted on ungrazed and undisturbed monospecific swards of blue grama, a tufted, sod-forming, warm-season, perennial shortgrass which is the dominant species and primary forage plant in the shortgrass steppe (Hyder et al. 1975).

Vegetation was sampled within randomly placed square $\left(0.7 \mathrm{~m}^{2}\right)$ quadrats. For graminoid sampling, experimental units of at least $0.3 \mathrm{~m}^{2}$ and less than $0.8 \mathrm{~m}^{2}$ provide a stable coefficient of variation, while maximizing the amount of information per hour of labor when high precision is required (Evans and Jones 1958, McIntyre 1976). A square wood frame with an inner grid comprised of 16 strings set at $10-\mathrm{cm}$ intervals along both axes of the frame was placed $4 \mathrm{~cm}$ above the ground. Basal cover of tillers was measured to the nearest millimeter along each string, for a total of $13.3 \mathrm{~m}$ of line measurements per quadrat. At alternate intersections of 2 strings, the nearest blue grama tiller was selected, and length $(\mathrm{mm})$

\footnotetext{
Authors are ecologist, U.S. Fish and Wildlife Service, 2627 Redwing Road, Fort Collins, Colo. 80526; senior research scientist, Natural Resource Ecological Laboratory, and associate professor, Department of Range Science, Colorado State University, Fort Collins 80523; professor, Range Management Division, University of Wyoming, Laramie 82071; ecologist, Division of Ecology Sciences, Man and the Biosphere program, UNESCO, Paris, France. At the time of this study, Williamson and Dyer were graduate student and professor, respectively, Department of Fishery and Wildlife Biology, Colorado State University.

The authors wish to thank Carol Simmons for expert editorial assistance.

This research was supported by NSF grants DEB 76-82821 and BSR 84-06660.

Manuscript accepted 6 November 1986.
}

of each blade was recorded. Percent basal cover and mean total blade length per tiller ( $n=32$ ) were calculated for each frame placement.

In 1979, calibration data obtained on 5 dates during the growing season were pooled to compute double sampling regression coefficients. Fifty percent of the calibration samples were chosen from areas with a relatively high biomass, $25 \%$ from areas with a relatively low biomass, and $25 \%$ from areas with an intermediate biomass. Sampling occurred on 21 May (11 plots), 28 May (10 plots), 12 June (10 plots), 22 June (5 plots), and 13 July (10 plots). Vegetation on calibration plots was measured for blade lengths and basal cover, clipped at ground level, and oven dried at $60^{\circ} \mathrm{C}$ for 72 hours. Calibrations of percent basal cover, total blade length per tiller, and standing crop index (percent basal cover - mean total blade length per tiller) vs. plant biomass were obtained by using a least squares fit of a zero-intercept linear regression. To evaluate temporal variation in the regression coefficient, we calibrated again in 1980, on 5 and $6 \mathrm{June}$ ( 16 plots) and 24 and $25 \mathrm{July}$ (18 plots).

\section{Results and Discussion}

Sampling techniques that utilize density and height measurements are attempts to relate volume (area $\bullet$ height) to biomass (Uresk et al. 1977). Our standing crop index (a volume measurement) showed a distinct improvement in goodness of fit over either percent basal cover (an area measurement) or total blade length (a height measurement) alone (Figs. 1 and 2A). The correlation coeffi cient for all data in 1979 (Fig. 2A) of 0.93 (45 d.f.) was highly significant $(P<0.01)$. Preassignment of the value of zero to the intercept (Ahmed et al. 1983) resulted in a minor decrease in $r^{2}$ (from 0.868 to 0.860 ) but provided a better fit in the low range of

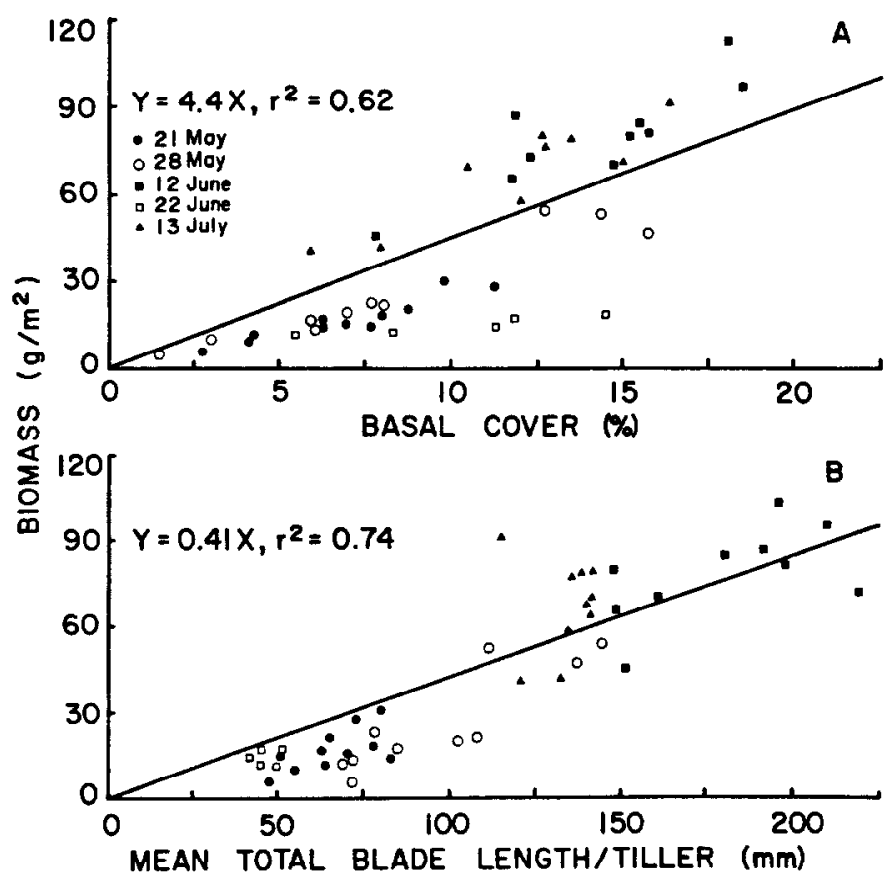

Fig. 1. Regression estimates of blue grama biomass based on $(A)$ percent basal cover and $(B)$ mean total blade length per tiller on 5 dates in 1979. 

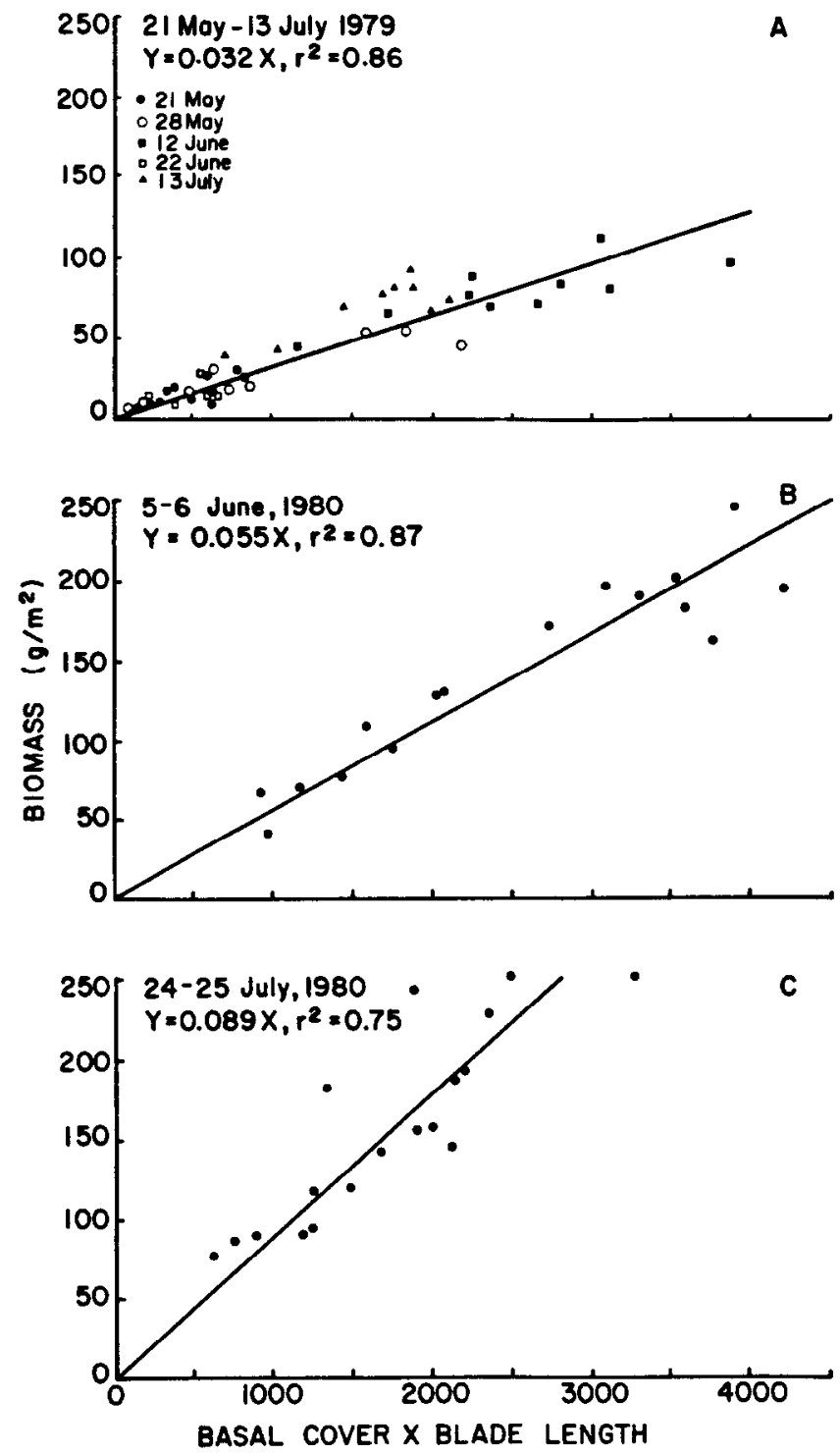

Fig. 2. Regression estimates of blue grama biomass based on the product of percent basal cover and total blade length per tiller on (A) 21 May to 13 July 1979, (B) 5-6 June, 1980, and (C) 24-25 July 1980.

standing crop index values. Although total blade length per tiller on 1979 calibration plots had greater predictive capability than percent basal cover (Fig. 1), there was a substantial underestimation of biomass in the low range $(0$ to $100 \mathrm{~mm})$ of total blade length. Basal cover has been used alone as an index of graminoid biomass (Anderson and Kothmann 1982). However, when basal cover is high, the high variability of standing crop estimates can preclude its use (Pasto et al. 1957). In this study, variability in the relationship between blue grama biomass and percent basal cover increased greatly when basal cover exceeded 10\% (Fig. 1A).

Average blade length has also been used as an indicator of standing crop in some species (Chapman 1976); however, it is only a fair indicator of blue grama biomass (Turner and Klipple 1952). Sharrow (1981) reported maximum tiller length is a valuable indicator of tiller weight for shortgrasses. We utilized total blade length per tiller because it accounts for both total number of blades and blade length and therefore was a potentially better indicator of shortgrass biomass than average blade length, maximum blade length, or maximum tiller length.

Year-to-year variation in the weight:volume ratio was indicated by the different regression coefficients obtained in the 1979 and 1980 calibrations (Fig. 2). As was also reported by Turner and Klipple (1952), variation within the growing season was found in this study; the regression coefficient in late July was 0.089 , compared with 0.055 in early June (Fig. 2, B and C). This difference reflects a higher dry weight:volume ratio in late July than in early June. Recalibration for each nondestructive sampling period should increase the accuracy of biomass estimates, especially for high biomass plots.

The usefulness of an indirect measure of standing crop depends on precision of the estimate and on stability of the regression coefficients (Reppert et al. 1962). For this study, optimizing precision of blade length and basal cover estimates was defined as minimizing variation in each of the 2 types of measurements (basal cover and blade length) subject to the fixed cost constraint that average time per plot should not exceed 20 minutes with 2 people measuring and 1 recording. Basal cover measurements require minimal time for a large sample but are subjective where plant limits are not well defined (Tothill 1976). Measurements of total blade length per tiller are more objective; however, this requires that each blade on a tiller be measured to achieve desired levels of precision. A sampling scheme utilizing $13.3 \mathrm{~m}$ of line transects ( $<10$ minutes) and blade measurements on 32 tillers ( $<10$ minute) per plot was found to optimize the accuracy and precision of plants measurements in this study.

To minimize the bias inherent in least squares regression estimates, only straight line regressions were used (McIntyre 1976). We defined optimizing the stability of the regression coefficient as minimizing least squares variation from observed values (i.e., maximizing precision) while maintaining goodness of fit throughout the range of biomass values (i.e., maintaining accuracy), subject to the constraint that all calibration plots should be measured and clipped in 1 team-day ( 3 person-days). Using these constraints, 16 calibration plots were measured in 1 team-day. We recommend this technique in experiments requiring nondestructive estimates of aerial biomass changes through time.

\section{Literature Cited}

Ahmed, J., C.D. Bonham, and W.A. Laycock. 1983. Comparison of techniques used for adjusting biomass estimates by double sampling. $\mathbf{J}$. Range Manage. 36:217-221.

Anderson, D.M., and M.M. Kothmann. 1982. A two-step sampling technique for estimating standing crop of herbaceous vegetation. J. Range Manage. 35:675-677.

Chapman, S.B. 1976. Production ecology and nutrient budgets. p. 157-228. In:S.B. Chapman (ed.). Methods in plant ecology. John Wiley and Sons, Inc., New York.

Crafts, E.C. 1938. Height-volume distribution in range grasses. J. Forestry 36:1182-1185.

Evans, R.A., and M.B. Jones. 1958. Plant height times ground cover versus clipped samples for estimating forage production. Agron. J. 50:504-506.

Hyder, D.N., R.E. Bement, E.E. Remmenga, and D.F. Hervey. 1975. Ecological responses of native plants and guidelines for management of shortgrass range. USDA Tech. Bull. 1503.

Lauenroth, W.K., J.L. Dodd, and P.L. Sims. 1978. The effects of water-and nitrogen-induced stresses on plant community structure in a semiarid grassland. Oecologia 36:211-222.

McIntyre, G.A. 1976. Statistical aspects of vegetation sampling. p. 8-21. In: L. 't Mannetje (ed.). Measurement of grassland vegetation and animal production. Commonwealth Bureau of Pastures and Field Crops Bull. 52. Hurley, Berkshire, England.

Pasto, J.K., J.R. Allison, and J.B. Washko. 1957. Ground cover and height of sward as a means of estimating pasture production. Agron. J. 49:407-409.

Reppert, J.N., M.J. Morris, and C.A. Graham. 1962. Estimation of herbage on California annual-type range. J. Range Manage. 15:318-323.

Sharrow, S.H. 1981. Tiller length vs. tiller weight: applications to plant growth studies. J. Range Manage. 34:354-356.

t Mannetje, L. 1976. Measuring quantity of grassland vegetation. P. 63-95. In: L. 't Mannetje (ed.). Measurement of grassland vegetation and animal production. Commonwealth Bureau of Pastures and Field Crops Bull. 52. Hurley, Berkshire, England. 
Tothill, J.C. 1976. Measuring botanical composition of grasslands. p. 22-62. In: L. 't Mannetje (ed.). Measurement of grassland vegetation and animal production. Commonwealth Bureau of Pastures and Field Crops Bull. 52. Hurley, Berkshire, England.

Turner, G.F., and G.E. Klipple. 1952. Growth characteristics of blue grama in northeastern Colorado. J. Range Manage. 5:22-28.
Uresk, D.W., R.O. Gilbert, and W.H. Rickard. 1977. Sampling big sagebrush for phytomass. J. Range Manage. 30:311-314.

Williamson, S.C. 1983. The herbivore optimization hypothesis: A sampling design, experimental examination and simulation. Ph.D. Diss., Colorado State Univ., Fort Collins. 